\title{
Killer whales are attracted to herring fishing vessels
}

\author{
Evert Mul $^{1, *}$, Marie-Anne Blanchet ${ }^{1,5}$, Brett T. McClintock ${ }^{2}$, W. James Grecian ${ }^{3}$, \\ Martin Biuw ${ }^{4}$, Audun Rikardsen ${ }^{1}$ \\ ${ }^{1}$ Faculty of Biosciences, Fisheries and Economics, UiT The Arctic University of Norway, 9037 Tromsø, Norway \\ ${ }^{2}$ Marine Mammal Laboratory, NOAA/NMFS Alaska Fisheries Science Center, Seattle, WA 98115, USA \\ ${ }^{3}$ Sea Mammal Research Unit, Scottish Oceans Institute, University of St Andrews, St Andrews KY16 8LB, UK \\ ${ }^{4}$ Institute of Marine Research, FRAM - High North Research Centre for Climate and the Environment, 9007 Tromsø, Norway
}

${ }^{5}$ Present address: Norwegian Polar Institute, 9296 Tromsø, Norway

\begin{abstract}
Marine mammals and fisheries often target the same resources, which can lead to operational interactions. Potential consequences of operational interaction include entanglements and damaged or reduced catches but also enhanced foraging opportunities, which can attract marine mammals to fishing vessels. Responsible fisheries management therefore requires detailed knowledge of the impact of these interactions. In northern Norway, killer whales Orcinus orca are frequently observed in association with large herring aggregations during the winter. We use a combination of biotelemetry and fisheries data to study if, to what extent and at what distances killer whales are attracted to fishing activity. Twenty-five satellite transmitters were deployed on killer whales at herring overwintering and spawning grounds, often near fishing vessels. Over $50 \%$ of the killer whale core areas of high usage overlapped with the fisheries core areas, and individual whales spent up to $34 \%$ of their time close to active fishing. We used a 3state hidden Markov model to assess whether killer whale movements were biased towards fishing activities. Of the overall whale movements, $15 \%$ (CI $=11-$ $21 \%$ ) were biased towards fishing activities, with marked heterogeneity among individuals $(0-57 \%)$. During periods of active fishing, whale movements were biased towards fishing events $44 \%$ (CI $=24-$ $66 \%$ ) of the time, with individual percentages ranging from 0 to $79 \%$. Whales were more likely to be attracted when they were within $20 \mathrm{~km}$. This information can be used in fishery management to consider potential consequences for fishers and whales.
\end{abstract}

KEY WORDS: Fishery interactions · Killer whales · Orcinus orca $\cdot$ Herring fishery $\cdot$ Behaviour $\cdot$ Hidden Markov model $\cdot$ momentuHMM $\cdot$ Attraction

${ }^{*}$ Corresponding author: evert.mul@uit.no

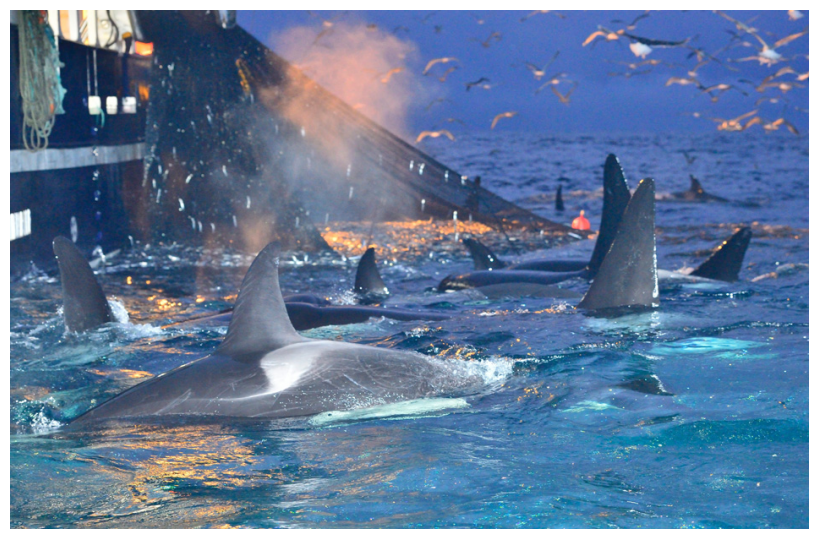

In northern Norway, killer whales often forage near herring fisheries during the winter, as the fisheries may present beneficial foraging opportunities for them.

Photo: Evert Mul

\section{INTRODUCTION}

Commercial fisheries are present in all the world's oceans and can affect marine wildlife and ecosystems in various ways (Botsford 1997). Marine top predators, such as marine mammals, seabirds, sharks and sea turtles, often inhabit the same regions and share resources with a variety of fisheries. As a result, their movements overlap temporally and spatially, leading directly to operational interactions, which are defined as direct contacts with operational fishing gear (Northridge 1991, Read et al. 2006, Read 2008). Over the last decades, increasing fishing

() E. Mul, M.-A. Blanchett, W. J. Grecian, M. Biuw, A Rikardsen and, outside the USA, the US Government 2020. Open Access under Creative Commons by Attribution Licence. Use, distribution and reproduction are unrestricted. Authors and original publication must be credited. 
activities have caused increased operational interactions between fisheries and marine top predators (Read et al. 2006, Read 2008, Northridge et al. 2017).

Consequences of these interactions can be neutral (no effect), positive or negative for either the animals, the fisheries or both. Top predators may benefit from fisheries, as fishing activity may provide good foraging opportunities by immobilizing or aggregating prey or by relocating prey to the surface. Predators can either take fish that have been captured by the fishers (depredation) or target discarded or escaped fish or fish that aggregate around a fishing net (Söffker et al. 2015, Tixier et al. 2019). As a result, some species are attracted to fishing activity. Similarly, fishers may also be attracted to top predators, which might lead them to commercially important prey species (Escalle et al. 2015). However, operational interactions can also have adverse consequences. Fisheries may lose revenue due to depredation or competition, lost or damaged fishing gear or increased operation time (Kock et al. 2006, Güçlüsoy 2008, Tixier et al. 2019). A wide range of seabirds, sea turtles, sharks and marine mammals die in various fishing gears around the world as a result of operational interactions (Moore et al. 2009, Abdulqader et al. 2017, Northridge et al. 2017, Carretta et al. 2019). The foraging benefits near fishing activity can provide long-term effects for the killer whale population, such as increased calving rate (Tixier et al. 2015). Ultimately, these effects can cascade through the ecosystem in which the killer whales are the top predator. Studying the short-term behavioural response of killer whales to fisheries can help to identify long-term consequences that fisheries may have on killer whales in Norway. Little is known about the mechanisms behind the interaction between fisheries and marine mammals and how animal behaviour is influenced by the presence of fishery activity (Richard et al. 2020). Studying the interaction between fisheries and marine mammals requires finescale animal movement data, which can be used to detect changes in the movement that may be induced by the fisheries (Mathias et al. 2012, Straley et al. 2014, Towers et al. 2019, Richard et al. 2020).

Killer whales Orcinus orca are highly mobile, globally distributed predators. In Norway, killer whales interact with industrial purse seine herring fisheries by feeding around the nets (Similä 2005, Rikardsen 2019). A recent estimate suggests that 15056 killer whales $(\mathrm{CV}=0.293,95 \% \mathrm{CI}=8423-26914)$ inhabit the northeastern Atlantic (Leonard \& Øien 2020), with more than 1100 known individuals in Norwegian waters (https://www.norwegianorca-id.no). Killer whale movements in Norway have been associated with their primary prey species: Norwegian springspawning (NSS) herring (Clupea harengus), which is the largest herring stock in the northeastern Atlantic (Dragesund et al. 1980, Similä et al. 1996, Kuningas et al. 2014, Jourdain et al. 2019). A large portion of the NSS herring stock often overwinters close to the Norwegian coast (Nøttestad \& Axelsen 1999, Huse et al. 2010, Rikardsen 2019). These winter aggregations have attracted large numbers of killer whales since the 1980s and humpback whales Megaptera novaeangliae since 2011 (Similä et al. 1996, Jourdain \& Vongraven 2017). After the winter, herring migrate southwards to spawn off the coast of western Norway (Huse et al. 2010). NSS herring is also an important commercial species, with a quota of $400000 \mathrm{t}$ in 2020. Purse seine fishing vessels congregate in the fjords during the winter (November-January) and overlap with killer whales and other top predators (Rikardsen 2019). However, little is known about the level of overlap and the nature of interactions between killer whales and herring fishing activity in northern Norway. The killer whales appear to be attracted to fishing activity during the winter herring aggregations but to what extent, how often, and from what distances remains unclear. Such knowledge should be considered when managing coastal fisheries.

The main objective of this study was to describe and quantify fine-scale overlap between herring fisheries and killer whale movements in northern Norway during and after winter herring aggregations, based on killer whale satellite tags and fishing vessel data. More specifically, our aims were to (1) identify areas of overlap between fishing activities and killer whales, (2) explore in detail the level of overlap in the fjords during the winter and offshore during the spring, and (3) investigate to what extent killer whales are attracted to fishing vessels, how often they are attracted and from what distances.

\section{MATERIALS AND METHODS}

\subsection{Killer whale instrumentation}

We equipped 25 killer whales with Argos satellite tags (Limpet SPOT 6/240, Wildlife Computers). The tags measured $54 \times 46 \times 20 \mathrm{~mm}$ and were surface mounted with 2 subdermal $68 \mathrm{~mm}$ titanium anchors. Tags were specifically deployed close to the middle of the dorsal fin, as this position yields better position data compared to a lower-placed tag (Mul et al. 2019). All killer whales were adult males, with the exception of 1 adult female. We used a $26 \mathrm{ft}$ open rigid inflatable boat 

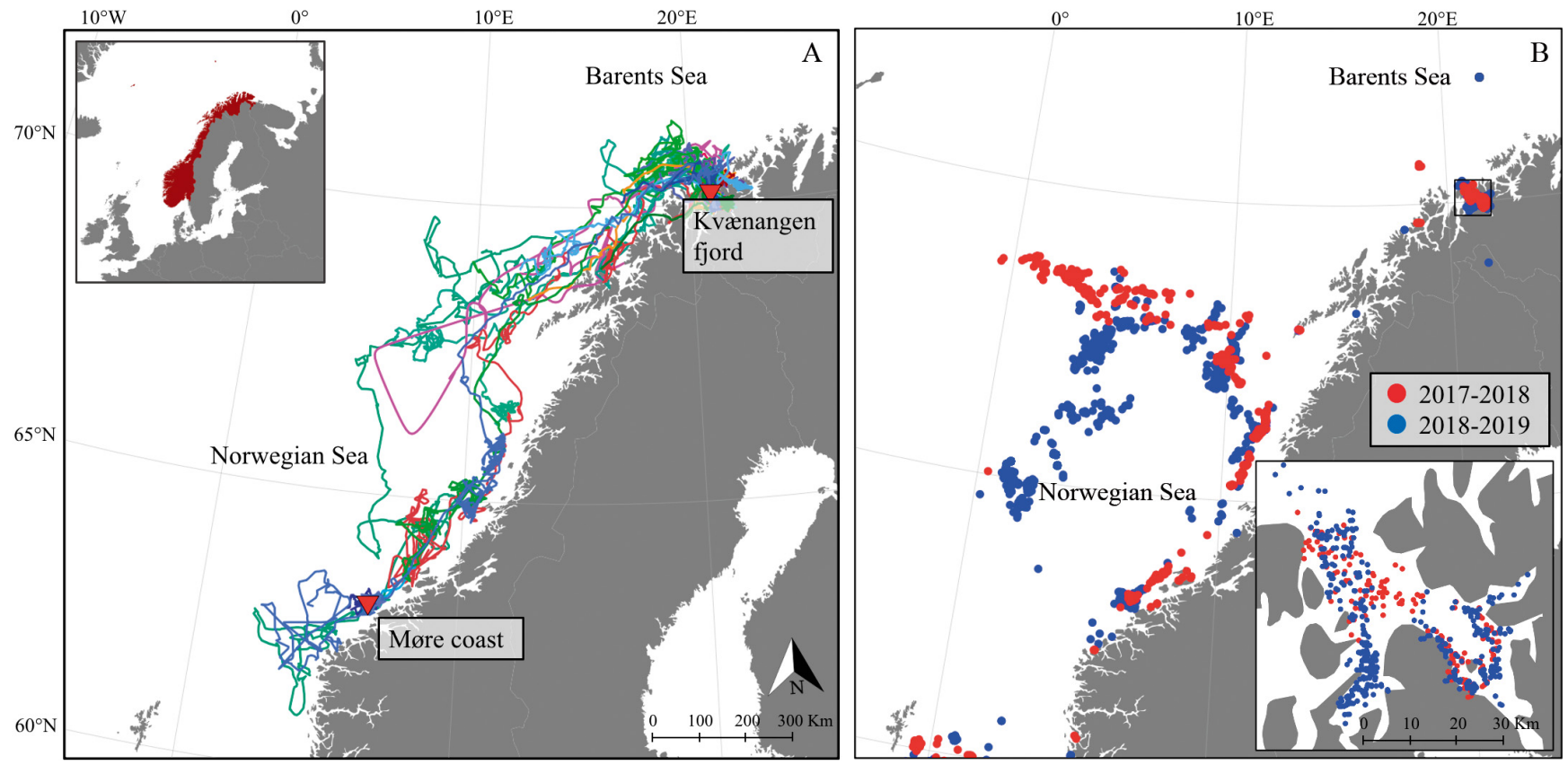

Fig. 1. (A) Northern Europe, showing the 2 tagging locations in Norway (red triangles). During the winter of 2017-2018, 11 killer whales were tagged in Kvænangen fjord. During the winter of 2018-2019, 10 killer whales were tagged in Kvænangen fjord, and 4 whales were tagged near the coast of Møre. The colored lines represent individual whale tracks. The inset shows Norway in a larger geographical extent. (B) Herring fishery locations in 2017-2018 and 2018-2019 during the periods when killer whale tags were in operation. The inset shows Kvænangen fjord

and an air rocket transmitter system tag applicator (https://restech.no) with 7 to 10 bar pressure at a distance of about 5 to $10 \mathrm{~m}$. The tags were programmed to transmit 14 to 15 messages per hour for the first 40 to $45 \mathrm{~d}$. The number of transmissions was reduced to $8-10 \mathrm{~h}^{-1}$ for the following 35 to $45 \mathrm{~d}$ and to 55 transmissions per day for the remaining lifespan of the battery. We deployed 11 tags between 2 December 2017 and 20 January 2018 (hereafter first study period) and 10 tags between 26 October 2018 and 23 January 2019 (hereafter second study period) in Kvænangen fjord in northern Norway (Fig. 1A, Table 1). In addition, 4 tags were deployed between 16 and 17 February 2019 off the coast of Møre in the western part of Norway (Fig. 1A, Table 1). Killer whales were tagged in different locations, in different social groups and around different fishing vessels to avoid tagging multiple animals in the same social group. The techniques used in this study have previously been shown to have little or no long-term effect on the demography and behaviour of the killer whales (Reisinger et al. 2014). Tagging procedures were approved by the Norwegian Food Safety Authority (https://www.mattilsynet.no, permit: FOTS-ID 14135) and evaluated in the field by an accredited veterinarian (Mattilsynet Report no. 2017/279575).

\subsection{Fisheries data}

Electronic catch diaries from the fishing vessels were reported to the Norwegian Directorate of Fisheries (https://www.fiskeridir.no). We obtained these data with masked vessel identification, through the Institute of Marine Research (https://www.hi.no). In this study, we focused only on purse seine herring fishing vessels. NSS herring are caught throughout the year but with a peak winter season between October and January. According to our data, 189 purse seine vessels made approximately 3500 fishing trips in 2017. The fleet consists primarily of small vessels that are between 20 and $40 \mathrm{~m}$ in length and large vessels that are between 60 and 80 $\mathrm{m}$ in length. The latter operated primarily offshore. We only obtained fishery data that overlapped in time with the killer whale tracking data (Fig. 1B). The data consisted of fishing locations, start and end times of each fishing event and catch size. A fishing event is defined as starting when the nets are set and ending when the nets are completely hauled onto the fishing vessel. However, based on communication with fishers and with the Directorate of Fisheries, there is some variation among fishers regarding the reporting of these events. In addition, 
Table 1. Detailed overview of raw killer whale data, tag performance, reconstructed whale tracks (based on a correlated random walk) and number of locations near fishing activity

\begin{tabular}{|c|c|c|c|c|c|c|c|c|c|}
\hline \multirow[t]{2}{*}{ Location } & \multirow[b]{2}{*}{$\begin{array}{c}\text { Whale } \\
\text { ID }\end{array}$} & \multirow{2}{*}{$\begin{array}{c}\text { Tagging } \\
\text { date } \\
\text { (dd/mm/yyyy) }\end{array}$} & \multicolumn{3}{|c|}{ Raw locations } & \multirow[b]{2}{*}{$\begin{array}{l}\text { No. of } \\
\text { hourly } \\
\text { locations }\end{array}$} & \multicolumn{2}{|c|}{ - Reconstructed path -} & \multirow[b]{2}{*}{$\begin{array}{c}\text { No. of } \\
\text { locations } \\
<3 \mathrm{~km} \text { of } \\
\text { active } \\
\text { fisheries }\end{array}$} \\
\hline & & & $\begin{array}{c}\text { No. } \\
\text { of } \\
\text { locations }\end{array}$ & $\begin{array}{l}\text { Tracking } \\
\text { duration } \\
\text { (d) }\end{array}$ & $\begin{array}{l}\text { Average } \\
\text { no. of } \\
\text { locations } \\
\mathrm{h}^{-1}\end{array}$ & & $\begin{array}{l}\text { Cumulative } \\
\text { distance } \\
(\mathrm{km})\end{array}$ & $\begin{array}{c}\text { No. of } \\
\text { locations } \\
<100 \mathrm{~km} \\
\text { of active } \\
\text { fisheries }\end{array}$ & \\
\hline \multicolumn{10}{|c|}{ First study period } \\
\hline \multirow[t]{11}{*}{ Kvænangen } & 47572 & $02 / 12 / 2017$ & 240 & 12 & 0.8 & 287 & 810 & 205 & 97 \\
\hline & 47580 & 02/12/2017 & 1269 & 37 & 1.4 & 881 & 4129 & 135 & 54 \\
\hline & 47590 & $02 / 12 / 2017$ & 404 & 19 & 0.9 & 468 & 1364 & 310 & 135 \\
\hline & 47592 & 02/12/2017 & 523 & 23 & 0.9 & 555 & 2596 & 272 & 90 \\
\hline & 47594 & $02 / 12 / 2017$ & 680 & 34 & 0.8 & 827 & 3013 & 363 & 60 \\
\hline & 47582 & $03 / 12 / 2017$ & 317 & 40 & 0.3 & 954 & 5023 & 272 & 77 \\
\hline & 47581 & $10 / 01 / 2018$ & 212 & 8 & 1.1 & 188 & 570 & 59 & 28 \\
\hline & 47587 & $10 / 01 / 2018$ & 542 & 18 & 1.3 & 431 & 1753 & 73 & 19 \\
\hline & 47577 & $12 / 01 / 2018$ & 811 & 31 & 1.1 & 751 & 3384 & 75 & 15 \\
\hline & 47573 & $20 / 01 / 2018$ & 24 & 2 & 0.6 & 44 & 146 & 0 & 0 \\
\hline & 47574 & $20 / 01 / 2018$ & 35 & 3 & 0.4 & 79 & 614 & 1 & 0 \\
\hline \multicolumn{10}{|c|}{ Second study period } \\
\hline \multirow[t]{10}{*}{ Kvænangen } & 54013 & $26 / 10 / 2018$ & 681 & 38 & 0.7 & 914 & 3176 & 571 & 145 \\
\hline & 53561 & $28 / 10 / 2018$ & 1041 & 53 & 0.8 & 1277 & 6134 & 566 & 57 \\
\hline & 53559 & 06/11/2018 & 1112 & 57 & 0.8 & 1366 & 5180 & 605 & 141 \\
\hline & 54011 & $06 / 11 / 2018$ & 1267 & 64 & 0.8 & 1539 & 5260 & 687 & 175 \\
\hline & 83761 & 13/11/2018 & 557 & 26 & 0.9 & 629 & 2317 & 465 & 92 \\
\hline & 83760 & 16/11/2018 & 866 & 40 & 0.9 & 964 & 3712 & 462 & 7 \\
\hline & 53557 & 04/01/2019 & 1615 & 93 & 0.7 & 2239 & 9698 & 412 & 147 \\
\hline & 83764 & 06/01/2019 & 498 & 29 & 0.7 & 689 & 2742 & 366 & 111 \\
\hline & 83756 & 08/01/2019 & 1301 & 64 & 0.8 & 1531 & 8846 & 339 & 93 \\
\hline & 83768 & $23 / 01 / 2019$ & 1358 & 71 & 0.8 & 1696 & 10262 & 72 & 8 \\
\hline \multirow[t]{4}{*}{ Møre } & 83755 & 16/02/2019 & 116 & 14 & 0.4 & 329 & 1291 & 128 & 24 \\
\hline & 83752 & 17/02/2019 & 46 & 3 & 0.8 & 61 & 311 & 39 & 7 \\
\hline & 83754 & 17/02/2019 & 176 & 12 & 0.6 & 287 & 1308 & 106 & 22 \\
\hline & 179032 & 17/02/2019 & 1122 & 53 & 0.9 & 1270 & 8182 & 118 & 17 \\
\hline
\end{tabular}

fish-finding efforts and onsite pre- and post-fishing preparations were not included in the reported start and end times. To include all the potential cues that may attract the whales to the fishing site, we added $2 \mathrm{~h}$ before the start and after the finish of each fishing activity. We based this decision on personal observations in the field. NSS herring are caught with circling and closing purse seine nets. Since fishing vessels remained relatively stationary when hauling the net, we assigned each fishing event to 1 location corresponding to the start of the fishing event. Therefore, fishing events within a $3 \mathrm{~km}$ radius of each other and less than $4 \mathrm{~h}$ apart were grouped together. These threshold values were based on field observations in the study area. Grouped fishing activities were assigned to the mean latitude and longitude coordinates, the summed catch size, the earliest start time and the latest end time of all the fishing events.

\subsection{Data processing}

To account for both location uncertainty (e.g. Kuhn et al. 2009) and time irregularity in the killer whale Argos locations, we fitted a correlated random walk using a continuous-time state space model (Johnson et al. 2008) based on the location class and error ellipse estimates (McClintock et al. 2015). This method is based on a Kalman filter and estimates movement parameters, from which one or several animal paths, or imputations, can be reconstructed (McClintock 2017). We used 30 imputations for each killer whale track rather than 1 best fit path reconstruction to account for the uncertainty and error around the raw Argos locations. Locations were estimated at a $1 \mathrm{~h}$ time interval as a reasonable representation of the raw Argos data (range: 0.3-1.5 locations $\mathrm{h}^{-1}$, Table 1). We fitted the model using the crawl package (Johnson \& London 2018) via a wrap- 
per function from the momentuHMM package (McClintock \& Michelot 2018). All results based on the 30 realisations of each track were pooled using standard multiple imputation formulae (e.g. Rubin 1987). All data processing and analyses were performed with R statistical computing software, version 4.0.0 (R Core Team 2019).

\subsection{Large-scale overlap between whale movements and fishing activity}

We calculated the size of the areas of overlap between whales and fisheries distributions for each study period separately by identifying areas where killer whales and fishing events were more likely to occur. These core areas (CAs) were estimated by calculating the $50 \%$ contour of the utilisation distribution (UD) for fishing events and killer whales. The UD is an estimation of the probability density of an animal's occurrence in space (Samuel et al. 1985). The fisheries UDs were calculated for each study period, based on a least squares cross-validation kernel method (Worton 1989, Horne \& Garton 2006), using the adehabitatHR package in $\mathrm{R}$ (Calenge 2006). Since the killer whale data were based on consecutive locations rather than independent points such as the fishery data, we used a Brownian bridge method to calculate killer whale UDs (Horne et al. 2007). We first calculated the UD for each of the 30 imputations for each whale over a $1 \times 1 \mathrm{~km}$ grid, using the BBMM package in $\mathrm{R}$ (Nielson et al. 2013). We then calculated an average individual UD and finally a cumulative UD per study period, by summing individual UDs. The spatial overlap between herring fisheries and whale movements was calculated as the percentage of the killer whale CA that overlapped with the fisheries CA. In addition, we calculated percentages of fisheries catches and fishing events within the killer whale CA for each study period.

\subsection{Fine-scale overlap between killer whales and fishing activity}

Overlap between whale movements and fishing activity on a finer scale was quantified by combining spatial overlap and temporal overlap. We calculated how many killer whale locations were within the detection range of fishing activity and how many of these locations were in close proximity to fishing activity. The maximum detection range was defined as $100 \mathrm{~km}$. This distance is an overestimation of the maximum distance at which killer whales can either detect fishing activity or react to it. An event at a distance of $100 \mathrm{~km}$ is unlikely to trigger an attraction response because it would take a killer whale $10 \mathrm{~h}$ to reach it at a maximum sustained speed of $10 \mathrm{~km} \mathrm{~h}^{-1}$ (Williams \& Noren 2009). In addition, killer whales were most likely unable to detect audible cues from fishing activity at a distance of $100 \mathrm{~km}$. For example, Erbe (2002) found that small whale-watching motorboats were only audible to killer whales at distances up to $16 \mathrm{~km}$. We defined close proximity to fishing activity as any location that was within $3 \mathrm{~km}$ of fishing activity, to account for the uncertainty in the whale locations and because fishing events within $3 \mathrm{~km}$ were grouped.

To assess when killer whales arrived relative to the start of the fishing activity, we calculated the percentage of close encounters where whales arrived after the start of the fishing activity. If killer whales are attracted to fishing activity, they should not respond before the start. However, in some cases, a fishing vessel might have been present at the fishing location even before the reported start of the fishing activity. For example, searching time and preparations for the fishery were not included in the reported fishing time. It is possible that killer whales have learnt to associate these activities with an upcoming fishing activity, and they may therefore be attracted to the fishing location even before the reported start of the fishery. For this reason, we performed this analysis twice, once with the reported start of the fisheries and once with the reported start minus $2 \mathrm{~h}$.

\subsection{Whale behaviour}

The effect of fishing activity on whale behaviour was assessed using a hidden Markov model (HMM). HMMs are discrete state space models that can be used to identify an unknown underlying state, such as a behavioural mode, based on indirect measures such as turning angle and Euclidean distance (step length) between consecutive locations (Langrock et al. 2012). Whale behaviour was categorised by the HMM into $N=3$ states: travelling movement (state 1), area-restricted movement (state 2) and attraction to the nearest fishing activity (state 3 ). Traveling movement was modelled as a correlated random walk with longer step lengths ((relative to area-restricted movements), area-restricted movement as a simple random walk 
and attraction as a biased random walk (with bias directed towards the nearest fishing activity). We used a gamma distribution to describe the step lengths and a von Mises distribution to describe the turning angles, using the distance and angle towards the nearest fishing activity as covariates on the parameters. Given the wide range of distances to fishing activity $(<1-100 \mathrm{~km})$, all distances were scaled by subtracting the mean and dividing by the SD. The state transition probability of the underlying state process was expressed as a function of the nearest distance to a fishing vessel $\left(x_{t}\right)$ :

$$
\gamma_{t i j}=\frac{\exp \left(\alpha_{i j}+x_{t} \beta_{i j}\right)}{\sum_{l=1}^{N} \exp \left(\alpha_{i l}+x_{t} \beta_{i l}\right)}
$$

where $\gamma_{t i j}$ is the transition probability from state $i$ at time $t$ to state $j$ at time $t+1$, and $\alpha_{i j}$ and $\beta_{i j}$ are logitscale intercept and slope parameters, respectively. This allowed us to assess the importance of the covariate on the probability of switching between states (Towner et al. 2016, Leos-Barajas et al. 2017, Grecian et al. 2018). To avoid overparameterisation while allowing constraints to be imposed on switches to the attraction state, we set $\alpha_{11}=\beta_{11}=\alpha_{22}=\beta_{22}=$ $\alpha_{32}=\beta_{32}=0$ for $i=j$. State transitions to the attraction state were prohibited when there was no fishing activity or the nearest fishing activity exceeded the maximum detection range (i.e. $\gamma_{t i 3}$ if no fishing or $x_{t}>$ $\mathrm{km})$. We similarly included linear and quadratic effects of the Euclidean distance between locations and the nearest fishing activity on the turn angle concentration parameter of the von Mises distribution for the attraction state $\left(\kappa_{3}\right.$ to investigate potential distance effects on the strength of bias towards fishing activity:

$$
\kappa_{3}=\exp \left(\alpha_{0}+\beta_{1} x_{t}+\beta_{2} x_{t}^{2}\right)
$$

Models were fitted by maximum likelihood using the $\mathrm{R}$ Package momentuHMM version 1.5.1 (McClintock \& Michelot 2020). We specified weakly informative $\operatorname{Normal}(0,100)$ prior constraints on $\alpha_{i j}$ and $\beta_{i j}$ to improve the numerical stability of the optimisation in the event any of the state transition probability estimates fell near a boundary. Movement parameters were independently estimated for each of the 30 imputations and then pooled. We used Akaike's information criterion (AIC; Burnham \& Anderson 2002) to evaluate the strength of evidence for distance effects on the strength of bias across the 30 imputations. Since changing the transition probability formula would result in different prior constraints, we were not able to use AIC to compare models with different structures for the state transition probabilities. For the best supported model, we used global state decoding (based on the Viterbi algorithm) to infer the most likely sequence of states. Stationary probabilities were used to assess overall state probabilities as a function of any covariates. Goodness of fit for the best supported model was assessed by visually examining pseudoresidual plots.

\section{RESULTS}

\subsection{Tagging and fishing data}

Tag retention time varied between 2 and $93 \mathrm{~d}$ (Table 1), with an average duration of $21 \mathrm{~d}$ during the first study period ( $\mathrm{SD}=14 \mathrm{~d}$ ) and $44 \mathrm{~d}$ during the second study period ( $\mathrm{SD}=26 \mathrm{~d}$ ). The cumulative length of individual paths varied from 146 to over $10000 \mathrm{~km}$ (mean = $3673 \pm 2997 \mathrm{~km})$, accounting for a mean daily distance of $105 \pm 31 \mathrm{~km}$ (Table 1). The time between the first and last transmission was $72 \mathrm{~d}$ for the first study period and $167 \mathrm{~d}$ for the second study period. The 11 killer whales instrumented during the first period accounted for 5465 hourly locations, and the 14 instrumented animals during the second period yielded 14791 hourly locations. During the first study period, $97952 \mathrm{t}$ of herring were caught in 566 fishing activities. During the second study period, $278735 \mathrm{t}$ of herring were caught in 1172 fishing activities. Fishery events lasted between 4 and $18 \mathrm{~h}$, with a mean of $6.55 \mathrm{~h}(\mathrm{SD}=1.67)$ or $6.72 \mathrm{~h}$ $(\mathrm{SD}=1.70)$ for the first and second study periods, respectively. Reported single catch sizes varied between 1 and 2442 t, with a median of $140 \mathrm{t}$.

\subsection{Large-scale overlap between whale distribution and fishing activity}

During both study periods, the main killer whale CA was located in Kænangen fjord, the principal tagging area. In addition, smaller offshore areas were included in the northern and southern parts of Norway including off the Møre county, where 4 individuals were tagged (Figs. 1 \& 2). During the first and second study periods, 53 and $93 \%$, respectively, of the whale CAs overlapped with the fisheries. In these areas of overlap, 16 and $32 \%$ of the total herring catches were fished, respectively representing 30 and $38 \%$ of the fishing events for each period. 

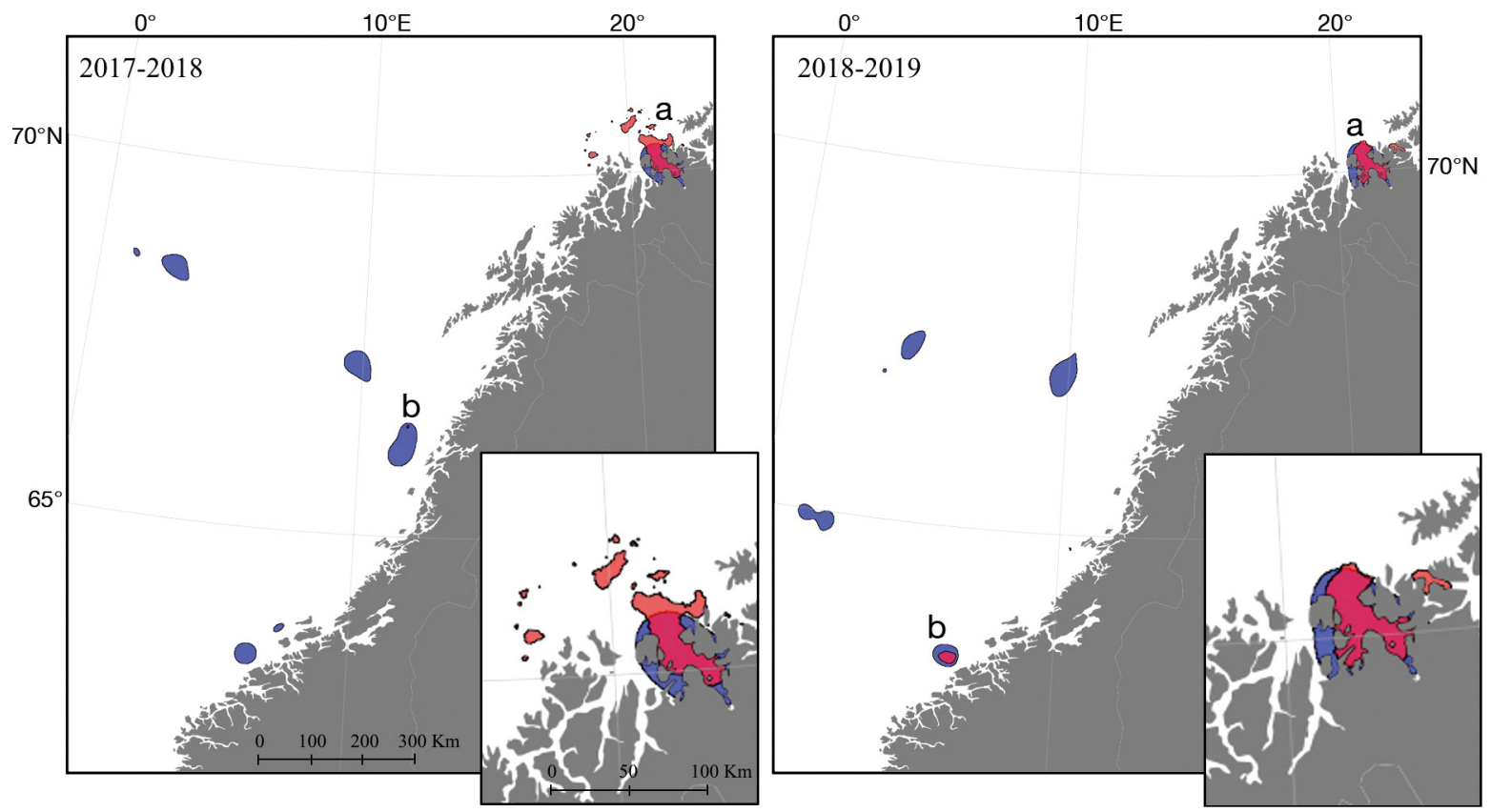

Fig. 2. Core areas (CAs) of killer whales (red) and fisheries (blue) for the first and second study periods, based on a $50 \%$ contour of the utilisation distribution. CAs that overlap with fisheries are marked a and b. Insets show the largest killer whale CAs (a) in more detail. Note that in both study periods, CAs are located near tagging locations

\subsection{Fine-scale overlap between killer whales and fishing activity}

Thirty-three percent of the killer whale locations were within $100 \mathrm{~km}$ of active fishing events, and $8 \%$ of all whale locations were within $3 \mathrm{~km}$ of the nearest fishing activity (Table 1). On average, individual whales spent $36 \%$ of their time (range: $0-74 \%$ ) within $100 \mathrm{~km}$ of the nearest active fishing event and 9\% (range: $0-34 \%$ ) within $3 \mathrm{~km}$ of fishing activity. Averaged over the 30 imputations per individual, $23 \%$ ( $\mathrm{SD}=0.3 \%$ ) of the fishing events that took place during the study periods were approached $(3 \mathrm{~km})$ by 1 or more killer whales. One whale never ventured within $100 \mathrm{~km}$ of any fishery, while another did so only once (Table 1). These 2 animals also had the shortest tracks ( 45 and $80 \mathrm{~h}$ ). Ten killer whales spent at least $10 \%$ of their time within $3 \mathrm{~km}$ of the nearest fishing activity. Of all the locations within $3 \mathrm{~km}$ of the nearest fishing activity, only $4.4 \%$ were not in or near Kvænangen fjord.

In $65 \%$ (range: $61-68 \%$ ) of the fishing events where a whale was within $3 \mathrm{~km}$ of a fishing activity, the whale arrived at the fishing location after the reported start of the fishery. If we accounted for the vessel searching time prior to the start of the fishery, whales were not yet present at the locations in $73 \%$ of the cases (range: 70-75\%). Fig. 3 shows an exam- ple of killer whale movement relative to the start of a fishing event. A more extensive example is provided as an animation in Supplement 1 (see Anim. 1 at www.int-res.com/articles/suppl/m652p001_supp/).

\subsection{Whale behaviour}

Based on average AIC weights across all 30 imputations (Table S1 in Supplement 2 at www.intres.com/articles/suppl/m652p001_supp/), the best supported model included linear and quadratic terms for the effect of distance to the nearest vessel on the turn angle concentration parameter for the attraction state $\left(\alpha_{0}=0.87, \mathrm{CI}=-0.75-2.48\right.$; $\beta_{1}=-3.02, \mathrm{CI}=-10.42-4.39 ; \beta_{2}=-7.26, \mathrm{CI}=$ $-14.17--0.34)$. When the nearest fishing activity was farther away $(10-20 \mathrm{~km})$, attraction towards the fishery was more directed as the distance decreased. However, at shorter distances $(<10 \mathrm{~km})$ the movements became less directed (Fig. 4). Distance had a weak positive effect on the stateswitching probability from area-restricted movement to travelling movement $\left(\beta_{21}=1.39\right.$, $\mathrm{CI}=-0.86-3.63)$, a weak negative effect on the probability of switching from area-restricted movement to the attraction state $\left(\beta_{23}=-2.15, \mathrm{CI}=-6.16-\right.$ 1.86) and a negative effect on the probability of 

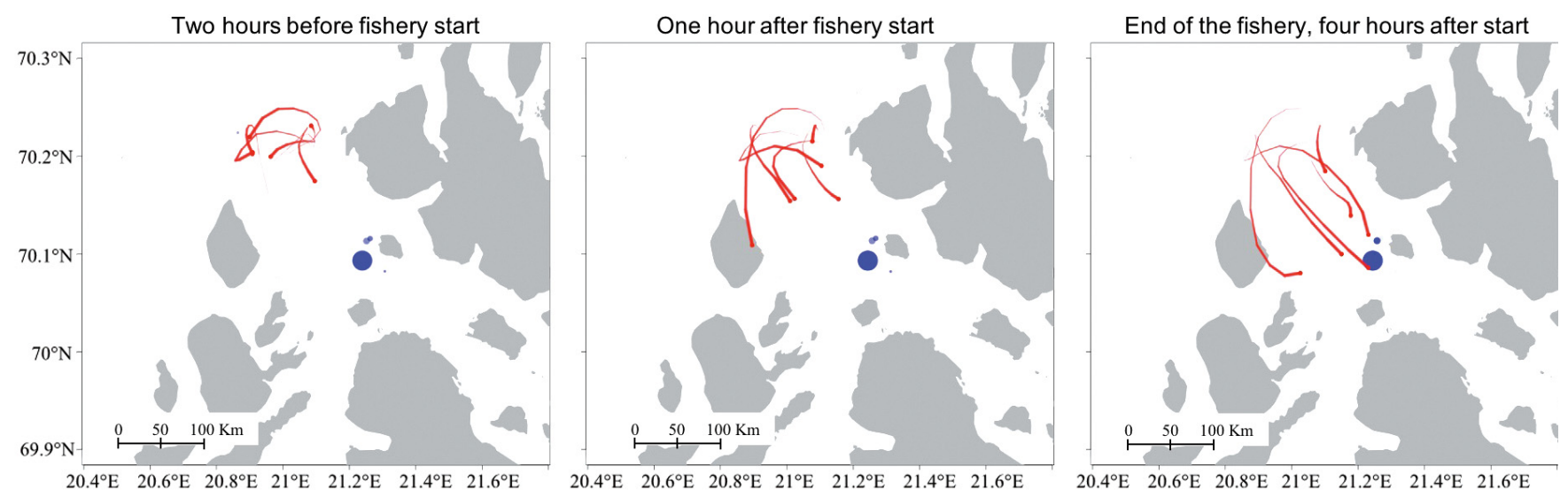

Fig. 3. Example of the attraction between killer whales (red lines) and fisheries (blue dots). Killer whale tracks are based on 1 imputation of a reconstructed path, and each frame represents a $3 \mathrm{~h}$ interval. The tail indicates the historical path of the whale and fades out after $10 \mathrm{~h}$. Fishery start and end represent the time the net is set until the time the net is retrieved, respectively.

Note that there may be some fishing-associated search activity prior to the reported start of the fishery

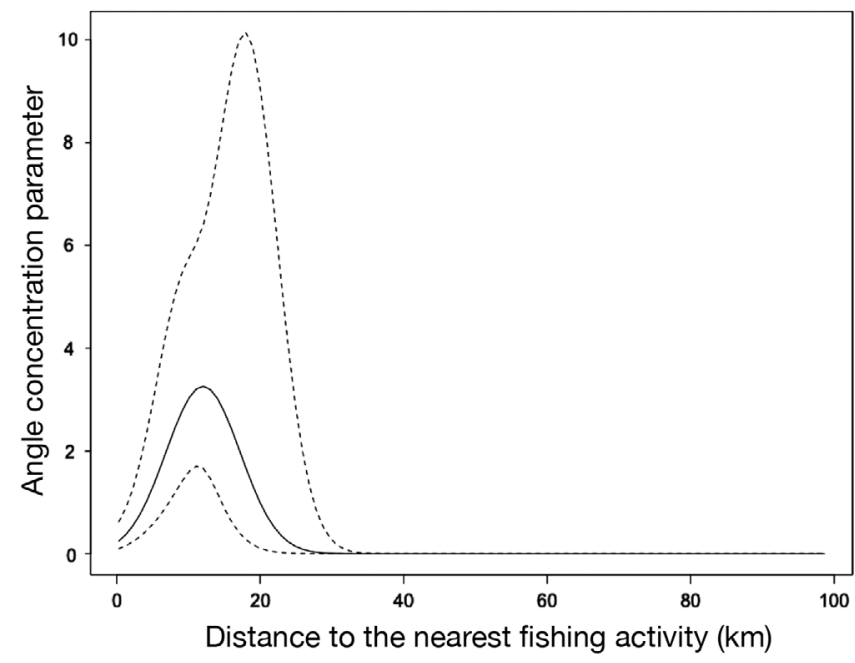

Fig. 4. Estimated effect of distance to the nearest fishing activity on the turn angle concentration parameter of the von Mises distribution for the attraction state $\left(\kappa_{3}\right)$. This figure shows that the strength of attraction to the nearest fishery is greatest at a distance of approximately $10 \mathrm{~km}$. Dashed lines indicate $95 \%$ confidence intervals

remaining in the attraction state $\left(\beta_{33}=-10.76\right.$, $\mathrm{CI}=-21.23--0.30$ ) (Fig. S1 in Supplement 2).

Global state decoding by the Viterbi algorithm assigned $15 \%(\mathrm{CI}=11-21 \%)$ of the overall $1 \mathrm{~h}$ time steps to the attraction state, $48 \%(\mathrm{CI}=40-54 \%)$ to the area-restricted movement state and $37 \%(\mathrm{CI}=$ $27-49 \%$ ) to the travelling movement state. Between 0 and $57 \%$ of the locations for individual whales were assigned to the attraction state. During periods of active fishing within a $100 \mathrm{~km}$ radius, $44 \%$ (CI = $24-66 \%$ ) of the whale movements were assigned to the attraction state, with individual percentages ranging from 0 to $79 \%$ (Table 2). Without fishing activity within a $100 \mathrm{~km}$ radius, the percentage of state assignments to travelling movement was $49 \%$ $(\mathrm{CI}=36-62 \%)$, and the percentage of area-restricted movement was $51 \%(\mathrm{CI}=38-64 \%)$. When fishing activity was within $100 \mathrm{~km}$, the stationary probability of travelling movement appeared to increase with the distance to the nearest fishing activity, while the probability of attraction appeared to decrease (Fig. S2 in Supplement 2). Twenty-three of the whales were attracted $\geq 10 \%$ of the time they were within $100 \mathrm{~km}$ of the nearest fishing activity, and 10 whales were attracted $\geq 50 \%$ (Table 2). Two whales had zero or 1 location within $100 \mathrm{~km}$ of the nearest fishing activity and could therefore not have been attracted to any fishing activity.

Plots of the pseudo-residuals indicated that the model fitted the data well (Fig. S3 in Supplement 2). There appeared to be some lack of fit in the step lengths, which could be attributable to a small amount of periodicity in the data and/or to unexplained variation in the step length distributions that appears to be largely attributable to 1 or 2 individual whale tracks that had relatively short or relatively long step lengths compared to the overall average.

\section{DISCUSSION}

Our results reveal a strong spatial and temporal overlap between killer whale Orcinus orca distribution and herring Clupea harengus fishing activity in northern Norway during the winter. All but 2 of the tagged whales encountered fishing activity at close 
Table 2. Percentage of time steps assigned to each state for locations within $100 \mathrm{~km}$ of the nearest fishing activity. Values in parentheses are SEs of the percentages. States were assigned by global state decoding of the hidden Markov model. Whale 47573 did not have locations within $100 \mathrm{~km}$ of an active fishery. NA: not applicable

\begin{tabular}{|lcccc|}
\hline $\begin{array}{l}\text { Whale } \\
\text { ID }\end{array}$ & Location & $\begin{array}{c}\text { Traveling } \\
\text { movement } \\
(\%)\end{array}$ & $\begin{array}{c}\text { Area-restricted } \\
\text { movement } \\
(\%)\end{array}$ & $\begin{array}{c}\text { Attraction to the } \\
\text { nearest fishing } \\
\text { activity }(\%)\end{array}$ \\
\hline 47572 & 205 & $0(0)$ & $21(23)$ & $79(23)$ \\
47580 & 135 & $16(16)$ & $23(19)$ & $61(22)$ \\
47590 & 310 & $0(0)$ & $28(19)$ & $72(19)$ \\
47592 & 272 & $15(7)$ & $27(21)$ & $58(19)$ \\
47594 & 363 & $14(7)$ & $49(10)$ & $37(8)$ \\
47582 & 272 & $19(8)$ & $32(15)$ & $50(15)$ \\
47581 & 59 & $0(0)$ & $27(21)$ & $73(21)$ \\
47587 & 73 & $2(2)$ & $49(12)$ & $49(12)$ \\
47577 & 75 & $11(15)$ & $51(14)$ & $38(12)$ \\
47573 & 0 & NA & NA & NA \\
47574 & 1 & $100(0)$ & $0(0)$ & $0(0)$ \\
54013 & 571 & $1(3)$ & $49(13)$ & $50(14)$ \\
53561 & 566 & $50(17)$ & $33(16)$ & $16(7)$ \\
53559 & 605 & $8(3)$ & $49(12)$ & $44(13)$ \\
54011 & 687 & $3(2)$ & $49(11)$ & $48(11)$ \\
83761 & 465 & $4(4)$ & $57(8)$ & $39(9)$ \\
83760 & 462 & $10(6)$ & $80(24)$ & $10(20)$ \\
53557 & 412 & $3(5)$ & $33(20)$ & $64(21)$ \\
83764 & 366 & $4(5)$ & $38(20)$ & $58(18)$ \\
83756 & 339 & $24(14)$ & $29(15)$ & $47(17)$ \\
83768 & 72 & $68(14)$ & $15(12)$ & $17(8)$ \\
83755 & 128 & $1(4)$ & $58(12)$ & $41(12)$ \\
83752 & 39 & $85(13)$ & $5(9)$ & $10(11)$ \\
83754 & 106 & $11(6)$ & $48(15)$ & $42(14)$ \\
179032 & 118 & $88(10)$ & $3(5)$ & $8(8)$ \\
Overall & 6701 & $13(4)$ & $42(11)$ & $44(11)$ \\
& & & & \\
\hline & & & &
\end{tabular}

proximity, primarily in Kvænangen fjord (Fig. 2). The start of fishing activity triggered a change of behaviour, and killer whale movements were biased towards herring purse seiners, suggesting that killer whales were sometimes attracted to fishing activity.

Killer whales are attracted to fisheries around the world (Luque et al. 2006, Peterson et al. 2013, Escalle et al. 2015, Söffker et al. 2015, Towers et al. 2019), because fishing activities offer beneficial foraging opportunities (Tixier et al. 2015, Esteban et al. 2016). The fishing events in our study aggregated large quantities of herring at the surface in purse seine nets. This allowed killer whales to feed on the aggregated, stunned and disorganised herring outside of the net, or they may pick individual fish through the mesh of the net. The killer whales appeared to gather around the edges of the fishing net as soon as it was set, even before the herring were pumped into the vessel. They stayed near the edges of the net until the net was hauled out of the water and the last fish dispersed (A. Rikardsen \& E. Mul pers. obs.). Some killer whales were caught inside the nets, but most of them either escaped or were released successfully by the fishers. Although deaths have occurred, no official numbers have been published (Rikardsen 2019). In the absence of fishing vessels, killer whales often herd the herring towards the surface into a tight ball (carousel feeding) before they immobilise individual or several herring with a fluke slap (Similä \& Ugarte 1993). Carousel feeding is an elaborate cooperative feeding technique that comes at a relatively high energetic cost, compared to feeding on discarded herring from fishing activity. Earlier studies found that in the vicinity of herring fishing vessels, killer whales changed their foraging behaviour (Van Opzeeland et al. 2005), and carousel feeding was observed less frequently (Kuningas et al. 2014). It is unclear what cues killer whales respond to and how they detect the fishing activity. Sperm whales appear to respond to acoustic cues from long-line fishing gear (e.g. winching) or from propellor or engine sounds that indicate changes in speed (Thode et al. 2007, Mathias et al. 2012). Killer whales and sperm whales can follow long-line fishing vessels for hundreds of kilometers (Towers et al. 2019), suggesting that they respond to vessel-specific acoustic signals. It is possible that the killer whales in Norway also respond to acoustic cues from the fishing gear or fishing operation itself, such as winching, pumping or setting of the nets.

Our results show that overlap and attraction occurred primarily in and near the overwintering herring in the fjords. This might be because most of the recorded locations were inside Kvænangen fjord, where most of the tags were deployed. However, the CAs of the 4 whales that were instrumented off the coast in southern Norway overlapped less with active fishing activity. Whales that left the fjords also overlapped less often with fisheries, compared to when they were still in the fjords. This suggests that outside of the fjord, the whales might not react as strongly to fishing activity. Outside of the fjord, the herring and fishing activities are distributed over a larger area (Huse et al. 2010). Fishing activity may occur at distances too large for killer whales to either detect or respond to.

Herring is a keystone prey species for killer whales in Norway (Similä et al. 1996, Jourdain et al. 2020). However, the importance of herring in the whale diet varies among individuals, as some animals occasionally switch to other prey species (Jourdain et al. 
2020). Therefore, some individuals may be less attracted to herring overwintering grounds. In addition, inter-individual differences in foraging behaviour among herring-eating killer whales may cause differences in the utilisation of fisheries. Such differences in fisheries interaction have been observed in seabirds (Patrick et al. 2015). In our study, some individuals did not interact with fishing activity, even though they were tagged in areas with a high herring density. Perhaps these individuals were attracted to herring but not to fishing activity. Finally, there may be gender-associated differences in the attraction to fishing activity, as there are genderrelated differences in feeding behaviour (Baird et al. 2005). However, we observed both females and males in large numbers around the fishing vessels.

Our HMM indicated attraction between killer whales and fisheries and an effect of distance on the strength of bias towards the nearest fishing vessel. At very close range, the strength of attraction tended to decrease, suggesting that the animals began to switch towards area-restricted movement (possibly foraging) near the fishing vessels. Another possibility for the decreasing strength of attraction in close proximity to fishing events might be that herring density in the general area of the fishing event may be relatively high and therefore attractive to killer whales. Area-restricted movement and attraction therefore became difficult to distinguish within close range of the fisheries based solely on step lengths and turn angles. Additional model structure or data streams, such as dive activity data, accelerometer data or mandible movement (e.g. van Beest et al. 2019), would likely improve the ability of our model to distinguish between possible foraging and weaker attraction within close range of the fisheries. The effect of distance to the nearest vessel on the state transition probabilities was subject to large uncertainties, but the transition probabilities to the attraction state appeared to be negatively affected by distance. A confounding factor might have been the number of co-occurring fishing activities and the relatively close proximity between them. In our model, only the nearest fishing activity was considered as a potential attractor. However, killer whales could have been attracted to other fishing activities farther away. As a result, it is likely that the occurrence of attraction, as identified by the HMM, is an underestimation of the real occurrence of attraction. Other studies may not have had this issue (e.g. Pirotta et al. 2018), since there were fewer vessels operating at the same time.

Interactions between killer whales and fisheries may come at a cost. For example, killer whale entan- glements have been reported for this area (Rikardsen 2019), although deadly entanglements are considered to be rare (Reeves et al. 2017). Interaction may also lead to a predator dependency on the fishery (Tew Kai et al. 2013). In some fisheries, depredation by marine mammals results in reduced revenues (Hanselman et al. 2018, Tixier et al. 2020). Killer whales that were feeding near fishing vessels mostly targeted the fish outside the net (A. Rikardsen \& E. Mul pers. obs.), which does not impact the catch size for the fishers. The number of fishes that were taken from the nets appeared to be low, and the effect on the catch size may have been insignificant. Still, if a whale entered a purse seine net, the fishers had to attempt to release the whale, which would take time and could potentially mean the loss of (part of) the catch.

Our results indicate that whales indeed benefit from feeding in close vicinity to fishing activity, which suggest these activities provide a substantial resource subsidy to the whales. Resource subsidies to predators can lead to an increase in the abundance of the predator, changes in dietary preferences, changes in survival, reproduction or sociality, and changes in home ranges or behaviour (Oro et al. 2013, Newsome et al. 2015). These changes can further affect prey or other species that interact with killer whales. We have shown that killer whales are attracted to fishing activities during the overwintering of herring in the fjords. However, it is unclear if, and to what extent, killer whales interact with fisheries during this time and during the rest of the year. Further research is required to determine the longterm effect of the herring fishery and potential other fisheries on killer whales in Norway.

\section{CONCLUSIONS}

This study provided novel insight into fine-scale interactions between killer whales and herring fisheries in northern Norway. Herring forms an important part of the diet for killer whales in Norway, and fishing activity provides easy foraging opportunities specifically targeted by killer whales. Decreased foraging costs might decrease their overall energy budget, and these foraging opportunities might be important for the growth of the Norwegian killer whale population (e.g. Halpern et al. 2019). Although there have been few reports of negative consequences that herring fisheries may have on killer whales, it is important to consider the cumulative effects from increasing anthropogenic activities to understand the overall impact of anthropogenic activities on killer 
whales in Norway. Furthermore, if the interaction between whales and fisheries increases and becomes a challenge for the fishery, mitigation actions need to be taken to reduce the risk of negative outcomes for both the fishery and the whales.

Acknowledgements. E.M. was funded by a PhD scholarship from VISTA, which is a basic research programme in collaboration between The Norwegian Academy of Science \& Letters and Equinor. The fieldwork was partly financed by the Regional Norwegian Research Counsel (Whalefeast project, RFFNORD no. 282469). The findings and conclusions herein are those of the author(s) and do not necessarily represent the views of NOAA/NMFS. Any use of trade, product or firm names does not imply an endorsement by the US Government. The authors thank Emma Frances Vogel, Lisa Elena Kettemer, Sune Hansen, Kunuk Lennert, Trond Johnsen and Lars Kleivane, who helped during the collection of the killer whale data. We also thank Raul Primicerio, André Frainer, Jarad Pope Mellard and Paul Wensveen for their suggestions on early versions of the analysis and 3 anonymous reviewers for their valuable suggestions and comments on the manuscript.

\section{LITERATURE CITED}

Abdulqader EAA, Miller J, Al-Mansi A, Al-Abdulkader K, Fita N, Al-Nadhiri H, Rabaoui L (2017) Turtles and other marine megafauna bycatch in artisanal fisheries in the Saudi waters of the Arabian Gulf. Fish Res 196:75-84

Baird RW, Hanson MB, Dill LM (2005) Factors influencing the diving behaviour of fish-eating killer whales: sex differences and diel and interannual variation in diving rates. Can J Zool 83:257-267

Botsford LW (1997) The management of fisheries and marine ecosystems. Science 277:509-515

*Burnham KP, Anderson DR (2002) Model selection and inference: a practical information-theoretic approach, 2nd edn. Springer-Verlag, New York, NY

Calenge C (2006) The package adehabitat for the R software: a tool for the analysis of space and habitat use by animals. Ecol Modell 197:516-519

Carretta JV, Moore JE, Forney KA (2019) Estimates of marine mammal, sea turtle, and seabird bycatch from the California large-mesh drift gillnet fishery: 1990-2017. NOAA Tech Memo NOAA-TM-NMFS-SWFSC-619

Dragesund O, Hamre J, Ulltang Ø (1980) Biology and population dynamics of the Norwegian spring-spawning herring. Rapp P-V Reùn Cons Int Explor Mer 177:43-71

Erbe C (2002) Underwater noise of whale-watching boats and potential effects on killer whales (Orcinus orca), based on an acoustic impact model. Mar Mamm Sci 18:394-418

Escalle L, Capietto A, Chavance P, Dubroca L and others (2015) Cetaceans and tuna purse seine fisheries in the Atlantic and Indian Oceans: interactions but few mortalities. Mar Ecol Prog Ser 522:255-268

Esteban R, Verborgh P, Gauffier P, Giménez J, Foote AD, de Stephanis R (2016) Maternal kinship and fisheries interaction influence killer whale social structure. Behav Ecol Sociobiol 70:111-122
Grecian WJ, Lane JV, Michelot T, Wade HM, Hamer KC (2018) Understanding the ontogeny of foraging behaviour: insights from combining marine predator bio-logging with satellite-derived oceanography in hidden Markov models. J R Soc Interface 15:20180084

Güçlüsoy H (2008) Damage by monk seals to gear of the artisanal fishery in the Foça Monk Seal Pilot Conservation Area, Turkey. Fish Res 90:70-77

Halpern BS, Frazier M, Afflerbach J, Lowndes JS and others (2019) Recent pace of change in human impact on the world's ocean. Sci Rep 9:11609

* Hanselman DH, Pyper BJ, Peterson MJ (2018) Sperm whale depredation on longline surveys and implications for the assessment of Alaska sablefish. Fish Res 200:75-83

*Horne JS, Garton EO (2006) Likelihood cross-validation versus least squares cross-validation for choosing the smoothing parameter in kernel home-range analysis. J Wildl Manag 70:641-648

Horne JS, Garton EO, Krone SM, Lewis JS (2007) Analyzing animal movements using Brownian bridges. Ecology 88:2354-2363

*Huse G, Fernö A, Holst JC (2010) Establishment of new wintering areas in herring co-occurs with peaks in the 'first time/repeat spawner' ratio. Mar Ecol Prog Ser 409:189-198

Johnson DS, London JM (2018) crawl: an R package for fitting continuous-time correlated random walk models to animal movement data. Zenodo. https://doi.org/10.5281/ zenodo.596464

Johnson DS, London JM, Lea MA, Durban JW (2008) Continuous-time correlated random walk model for animal telemetry data. Ecology 89:1208-1215

* Jourdain E, Vongraven D (2017) Humpback whale (Megaptera novaeangliae) and killer whale (Orcinus orca) feeding aggregations for foraging on herring (Clupea harengus) in northern Norway. Mamm Biol 86:27-32

* Jourdain E, Ugarte F, Víkingsson GA, Samarra FIP and others (2019) North Atlantic killer whale Orcinus orca populations: a review of current knowledge and threats to conservation. Mammal Rev 49:384-400

Jourdain E, Andvik C, Karoliussen R, Ruus A, Vongraven D, Borgå K (2020) Isotopic niche differs between seal and fish-eating killer whales (Orcinus orca) in northern Norway. Ecol Evol 10:4115-4127

*Kock KH, Purves MG, Duhamel G (2006) Interactions between cetacean and fisheries in the Southern Ocean. Polar Biol 29:379-388

K Kuhn CE, Johnson DS, Ream RR, Gelatt TS (2009) Advances in the tracking of marine species: using GPS locations to evaluate satellite track data and a continuous-time movement model. Mar Ecol Prog Ser 393:97-109

Kuningas S, Similä T, Hammond PS (2014) Population size, survival and reproductive rates of northern Norwegian killer whales (Orcinus orca) in 1986-2003. J Mar Biol Assoc UK 94:1277-1291

* Langrock R, King R, Matthiopoulos J, Thomas L, Fortin D, Morales JM (2012) Flexible and practical modeling of animal telemetry data: hidden Markov models and extensions. Ecology 93:2336-2342

* Leonard D, Øien N (2020) Estimated abundances of cetacean species in the northeast Atlantic from two multiyear surveys conducted by Norwegian vessels between 2002-2013. NAMMCO Sci Publ 11

* Leos-Barajas V, Photopoulou T, Langrock R, Patterson TA, 
Watanabe YY, Murgatroyd M, Papastamatiou YP (2017) Analysis of animal accelerometer data using hidden Markov models. Methods Ecol Evol 8:161-173

Luque PL, Davis CG, Reid DG, Wang J, Pierce GJ (2006) Opportunistic sightings of killer whales from Scottish pelagic trawlers fishing for mackerel and herring off North Scotland (UK) between 2000 and 2006. Aquat Living Resour 19:403-410

Mathias D, Thode AM, Straley J, Calambokidis J, Schorr GS, Folkert K (2012) Acoustic and diving behavior of sperm whales (Physeter macrocephalus) during natural and depredation foraging in the Gulf of Alaska. J Acoust Soc Am 132:518-532

McClintock BT (2017) Incorporating telemetry error into hidden Markov models of animal movement using multiple imputation. J Agric Biol Environ Stat 22:249-269

McClintock BT, Michelot T (2018) momentuHMM: R package for generalized hidden Markov models of animal movement. Methods Ecol Evol 9:1518-1530

McClintock BT, Michelot T (2020) momentuHMM: maximum likelihood analysis of animal movement behavior using multivariate hidden Markov models. https://cran.rproject.org/package=momentuHMM

McClintock BT, London JM, Cameron MF, Boveng PL (2015) Modelling animal movement using the Argos satellite telemetry location error ellipse. Methods Ecol Evol 6:266-277

Moore JE, Wallace BP, Lewison RL, Žydelis R, Cox TM, Crowder LB (2009) A review of marine mammal, sea turtle and seabird bycatch in USA fisheries and the role of policy in shaping management. Mar Policy 33: 435-451

Mul E, Blanchet MAA, Biuw M, Rikardsen A (2019) Implications of tag positioning and performance on the analysis of cetacean movement. Anim Biotelem 7:11

Newsome TM, Dellinger JA, Pavey CR, Ripple WJ, Shores CR, Wirsing AJ, Dickman CR (2015) The ecological effects of providing resource subsidies to predators. Glob Ecol Biogeogr 24:1-11

Nielson MR, Sawyer H, McDonald TL (2013) BBMM: Brownian bridge movement model. https://cran.r-project.org/ package $=$ BBMM

Northridge SP (1991) An updated world review of interactions between marine mammals and fisheries. FAO Fish Tech Pap 251, Suppl 1. FAO, Rome

Northridge S, Coram A, Kingston A, Crawford R (2017) Disentangling the causes of protected-species bycatch in gillnet fisheries. Conserv Biol 31:686-695

Nøttestad L, Axelsen BE (1999) Herring schooling manoeuvres in response to killer whale attacks. Can J Zool 77 : 1540-1546

Oro D, Genovart M, Tavecchia G, Fowler MS, MartínezAbraín A (2013) Ecological and evolutionary implications of food subsidies from humans. Ecol Lett 16: 1501-1514

* Patrick SC, Bearhop S, Bodey TW, Grecian WJ, Hamer KC, Lee J, Votier SC (2015) Individual seabirds show consistent foraging strategies in response to predictable fisheries discards. J Avian Biol 46:431-440

Peterson MJ, Mueter F, Hanselman D, Lunsford C, Matkin C, Fearnbach H (2013) Killer whale (Orcinus orca) depredation effects on catch rates of six groundfish species: implications for commercial longline fisheries in Alaska. ICES J Mar Sci 70:1220-1232
Pirotta E, Edwards EWJ, New L, Thompson PM (2018) Central place foragers and moving stimuli: a hidden-state model to discriminate the processes affecting movement. J Anim Ecol 87:1116-1125

R Core Team (2019) R: a language and environment for statistical computing. R Foundation for Statistical Computing, Vienna. https://www.r-project.org/

* Read AJ (2008) The looming crisis: interactions between marine mammals and fisheries. J Mammal 89:541-548

* Read AJ, Drinker P, Northridge S (2006) Bycatch of marine mammals in US and global fisheries. Conserv Biol 20: 163-169

Reeves R, Pitman RL, Ford JKB (2017) Orcinus orca. The IUCN Red List of Threatened Species 2017: e.T15421A50 368125 (accessed Apr 2020)

* Reisinger RR, Oosthuizen WC, Péron G, Toussaint DC, Andrews RD, De Bruyn PJN (2014) Satellite tagging and biopsy sampling of killer whales at subantarctic Marion Island: effectiveness, immediate reactions and long-term responses. PLOS ONE 9:e111835

* Richard G, Bonnel J, Tixier P, Arnould JPY, Janc A, Guinet C (2020) Evidence of deep-sea interactions between toothed whales and longlines. Ambio 49:173-186

Rikardsen AH (2019) Winter whales. ToFoto, Harstad

Rubin DB (1987) Multiple imputation for nonresponse in surveys. Wiley, New York, NY

* Samuel MD, Pierce DJ, Garton EO (1985) Identifying areas of concentrated use within the home range. J Anim Ecol $54: 711$

* Similä T (2005) Interactions between herring fishery and killer whales in northern Norway. ICES CM 2005/R:03. www.ices.dk/sites/pub/CM Doccuments/2005/R/R0305. pdf (accessed 1 Nov 2019)

* Similä T, Ugarte F (1993) Surface and underwater observations of cooperatively feeding killer whales in northern Norway. Can J Zool 71:1494-1499

* Similä T, Holst JC, Christensen I (1996) Occurrence and diet of killer whales in northern Norway: seasonal patterns relative to the distribution and abundance of Norwegian spring-spawning herring. Can J Fish Aquat Sci 53: 769-779

Söffker M, Trathan P, Clark J, Collins MA, Belchier M, Scott $\mathrm{R}$ (2015) The impact of predation by marine mammals on Patagonian toothfish longline fisheries. PLOS ONE 10: e0118113

* Straley JM, Schorr GS, Thode AM, Calambokidis J and others (2014) Depredating sperm whales in the Gulf of Alaska: local habitat use and long distance movements across putative population boundaries. Endang Species Res 24:125-135

* Tew Kai E, Benhamou S, van der Lingen CD, Coetzee JC, Pichegru L, Ryan PG, Grémillet D (2013) Are Cape gannets dependent upon fishery waste? A multi-scale analysis using seabird GPS-tracking, hydro-acoustic surveys of pelagic fish and vessel monitoring systems. J Appl Ecol 50:659-670

* Thode A, Straley J, Tiemann CO, Folkert K, O'Connell V (2007) Observations of potential acoustic cues that attract sperm whales to longline fishing in the Gulf of Alaska. J Acoust Soc Am 122:1265-1277

*Tixier P, Authier M, Gasco N, Guinet C (2015) Influence of artificial food provisioning from fisheries on killer whale reproductive output. Anim Conserv 18:207-218

* Tixier P, Burch P, Richard G, Olsson K and others (2019) Com- 
mercial fishing patterns influence odontocete whalelongline interactions in the Southern Ocean. Sci Rep 9: 1904

Tixier P, Burch P, Massiot-Granier F, Ziegler P and others (2020) Assessing the impact of toothed whale depredation on socio-ecosystems and fishery management in wide-ranging subantarctic fisheries. Rev Fish Biol Fish 30:203-217

Towers JR, Tixier P, Ross KA, Bennett J, Arnould JPY, Pitman RL, Durban JW (2019) Movements and dive behaviour of a toothfish-depredating killer and sperm whale. ICES J Mar Sci 76:298-311

Towner AV, Leos-Barajas V, Langrock R, Schick RS and others (2016) Sex-specific and individual preferences for hunting strategies in white sharks. Funct Ecol 30: 1397-1407

Editorial responsibility: Peter Corkeron, Woods Hole, Massachusetts, USA van Beest FM, Mews S, Elkenkamp S, Schuhmann P and others (2019) Classifying grey seal behaviour in relation to environmental variability and commercial fishing activity - a multivariate hidden Markov model. Sci Rep 9:5642

* Van Opzeeland IC, Corkeron PJ, Leyssen T, Similä T, Van Parijs SM (2005) Acoustic behaviour of Norwegian killer whales (Orcinus orca), during carousel and seiner foraging on spring-spawning herring. Aquat Mamm 31: 110-119

Williams R, Noren DP (2009) Swimming speed, respiration rate, and estimated cost of transport in adult killer whales. Mar Mamm Sci 25:327-350

*Worton BJ (1989) Kernel methods for estimating the utilization distribution in home-range studies. Ecology 70 : 164-168

Submitted: June 16, 2020; Accepted: August 26, 2020 Proofs received from author(s): October 8, 2020 